\title{
CONICAL HOPPER DESIGN FOR MASS FLOW - CASE OF RED MUD
}

\author{
J. C. M. LOBATO, F. P. MASCARENHAS*, A. L. A. MESQUITA and A. L. A. MESQUITA \\ Federal University of Pará, Faculty of Mechanical Engineering \\ nando280@hotmail.com*
}

Article submitted in February/2016 and accepted in March/2016

DOI: $10.15628 /$ holos.2016.3662

\begin{abstract}
In many cases problems in silos may occur due to improper design of its geometry due to the nonconsideration of the flow properties of the material. One of the factors that affect the flow properties of materials is the moisture content, which allows the formation of cohesive arches in the material inside the silo avoiding the desirable mass flow type. Therefore, this paper aimed to analyze the flow properties of the red mud, for different moisture levels, in order to design a hopper that provide a mass flow in conical silos. Initially, the flow
\end{abstract}

properties of red mud were determined by laboratory testing using the Jenike shear tester, and then the design of the silo hopper was performed using Jenike and Enstad theories, i. e., the minimum diameter and angle of inclination of the hopper were determined for each moisture level. In order to validate the theoretical results, experimental results were obtained in laboratory for red mud powder using acrylic silos with different hoppers. The experimental results were found in good agreement with the theoretical results.

KEYWORDS: Bulk solid flow, Silo, Conical hopper, Red mud.

\section{DIMENSIONAMENTO DE TREMONHAS CÔNICAS PARA FLUXO MÁSSICO - O CASO DA LAMA VERMELHA}

\section{RESUMO}

Problemas em silos podem ocorrer, em muitos casos, devido ao incorreto dimensionamento de sua geometria por não considerar as propriedades de fluxo do material granulado. Um dos fatores que afetam as propriedades de fluxo do material é a umidade, que favorece a formação de arcos coesivos no material no interior do silo impedindo o fluxo mássico desejado. Portanto, este artigo objetivou analisar as propriedades de fluxo da lama vermelha, para diferentes teores de umidade, com o intuito de dimensionar a tremonha cônica de silos para fornecer um fluxo mássico do material. Inicialmente, as propriedades de fluxo da lama vermelha foram obtidas em laboratório utilizando a Célula de Cisalhamento Tipo Jenike e em seguida o dimensionamento da tremonha do silo foi realizado usando as teorias de Jenike e Enstad, ou seja, o diâmetro mínimo de descarga e o ângulo de inclinação foram determinados para cada teor de umidade. Ensaios em laboratórios usando silos de acrílicos com diferentes tremonhas foram realizados e os resultados experimentais apresentaram boa concordância com os resultados teóricos.

PALAVRAS-CHAVE: Fluxo de sólidos granulados, Silo, Tremonha cônica, Lama vermelha. 


\section{INTRODUCTION}

The mineral sector in Brazil plays a key role in economy of the Country. However, the extraction of mineral substances can cause environment problems. Red mud is a solid waste produced in the process of alumina extraction from bauxite (Figure 1). In order to reduce the amount of stored red mud, several applications have been studied such as brick production (Silva Filho et al., 2007; Mercury et al., 2010; Souza, 2010), removal of dyes from textile effluents (Silva Filho et al., 2008), and recovery of iron and titanium (Souza, 2010; Liu and Li, 2015).

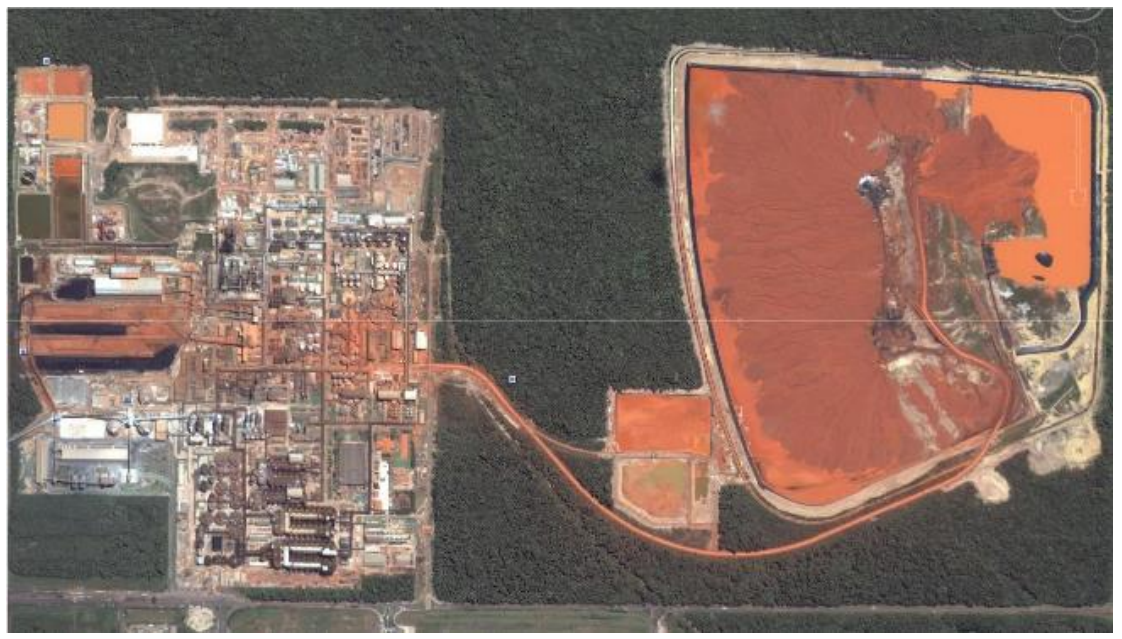

Figure 1: Picture of an industrial plant of bauxite processing showing the red mud deposit (Souza, 2010).

For any application of red mud it is common to store it in silos before treatment. Therefore, silos must be correctly designed for this purpose. Typically, there are two modes of product flow patterns to consider for the design of silos and hoppers - mass flow and funnel flow (Jenike, 1964). In mass flow (Figure 2a), during discharge, the first portion of the granular material entering the silo is the first to exit through the hopper outlet, i.e. it provides first-in, first-out flow with all of the material in motion during discharge. In funnel flow (Figure 2b), part of the product discharges through a preferential flow channel formed within the material in the silo, while the rest of the material remains stationary forming stagnant zones.

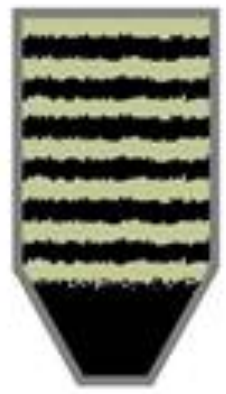

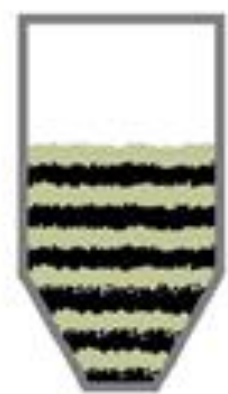

a)
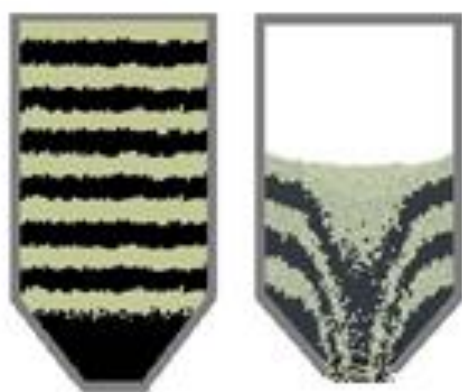

b)

Figure 2: a) Mass flow; b) Funnel flow. 
The mass flow is the uniform flow, which is preferred in design of silos. The funnel flow is acceptable if the bulk solid is coarse, free-flowing, not prone to cake, and if segregation is not important (Marinelli and Carson, 1992). Thus, in these conditions, the funnel flow can be used mainly where low headroom is required (Chase, 2006). However, the funnel flow is the situation where most of the problems of silos can occur.

In this context, this paper focuses on the characterization of flow properties of the red mud, for different moisture levels, in order to design hoppers of conical silos for mass flow. It is important to emphasize that the moisture content in the material can significantly alter the flow properties of these material.

The design of the hopper was developed based on the methodology proposed by Jenike (1964) where initially the hopper slope is found in order to guarantee the mass flow, and then the minimum size of the outlet opening of the silo is determined to avoid cohesive arching (Lopes Neto and Nascimento, 2013). From the Jenike approach, other researchers have published their design methodologies for mass flow, for example Enstad (1975), Arnold and McLean (1976a,b) and Walker (1966). Thus, in this work, the minimum outlet diameter is also determined by the Enstad's methodology (1975). In order to validate the theoretical results, experiments were performed in laboratory using acrylic silos using hoppers with different geometries.

\section{FLOW PROPERTIES DETERMINATION}

In Jenike theory, for a bulk solid flow in a hopper, it is necessary to know the shear stresses needed to initiate the flow. This means to identify the Yield Limit or Instantaneous Yield Locus (IYL) or simply Yield Locus $(\mathrm{YL})$ in shear stress $(\tau)$ versus normal stress $(\sigma)$ diagram. The $Y L$ is the envelope curve tangent to all Mohr stress circles which represents stress state at which the bulk solid starts to flow (Jenike, 1964). Several Mohr circles may be drawn that are tangent to YL. However, in order to identify the mainly properties to define the flowability, it is suffice only two circles. The first is a Mohr circle passing through the origin of the $\sigma, \tau$ - diagram (Figure 3 ). This circle represents the bulk solid state stress to initiate the flow, i.e. to cause the arch to collapse in a silo (Chase, 2006). The diameter of this minor circle is the "unconfined yield stress" $\left(\sigma_{c}\right)$. The second Mohr circle comprises the critical point (end point) of the YL. This circle represents the state of the material at the "compacting stress" or "consolidation stress" $\left(\sigma_{1}\right)$ (Figure 3). It is worthwhile to mention that the normal stresses in the Mohr circles for bulk solids analysis are positives for compression stresses and the shear stresses are all positives. That is why only positives semi-circle are plotted in the analyses.

Figure 3 shows both semi-circles which define $\sigma_{\mathrm{c}}$ and $\sigma_{1}$. The shape of an $\mathrm{YL}$ is a curve, but for practice reasons this curve is approximated by a straight line. The angle $\phi_{i}$ is the internal friction angle, which defines the slope of the linearized YL. The point that the straight line intercepts the $y$ axis is the cohesion (c). The straight line passing through the origin that is tangent to the largest Mohr circle at the end-point of yield locus (E) is the effective yield locus (EYL) and the effective angle of internal friction $\left(\varphi_{e}\right)$ is the slope of EYL (Chase, 2006; Shamlou, 1990; Chaves, 2011). 


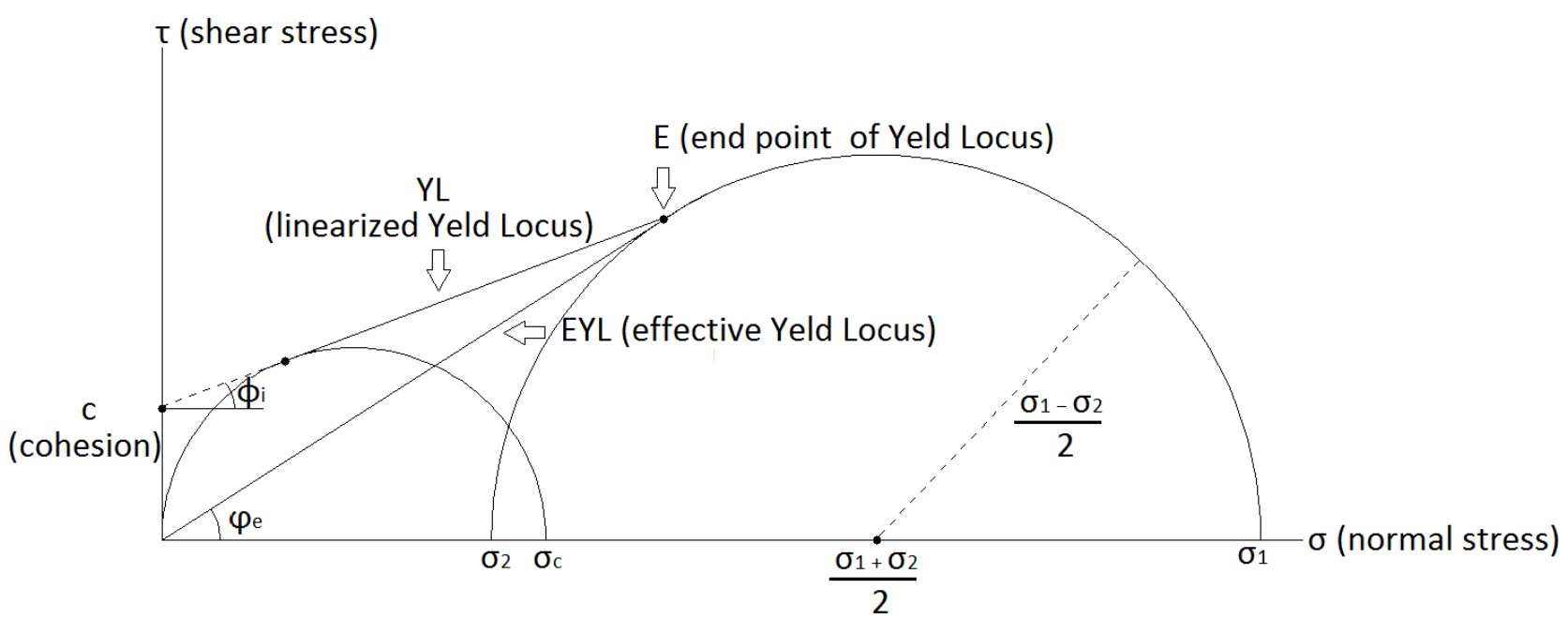

Figure 3: Yield locus for consolidate bulk solid.

The $\sigma_{c}, \sigma_{1}$ and a $\mathrm{YL}$ are obtained using a shear tester. The most popular shear tester is the Jenike Shear Tester (Figure 4 and Figure 5) and the Ring Shear Stress (Schulze, 2007; Koynov et al., 2015; Sun, 2016). The Jenike apparatus can also be used to measure the wall friction angle as shown in Figure $4 \mathrm{~b}$. The procedures for both tests (material/material and material/silo surface material characterization) can be found in D6128-97 ASTM Standard (ASTM, 1997). Figure 5 shows the Jenike tester used in this work. In Figure 5 can be noted the red mud inside the ring.

The YL (or IYL) is function of the consolidation state of the material. Performing several tests in a shear tests using different consolidation stresses, we can find different YLs. In Figure 6a we can see different Mohr semi-circles representing several state stresses that give different compacting stresses $\sigma_{1}$, different unconfined yield stress $\sigma_{c}$ and different $Y L s$. For each $Y L$ we have one $\sigma_{c}, \sigma_{1}$ pair. The plot of these pairs in a $\sigma_{1}, \sigma_{c}$-diagram defines the flow function FF or instantaneous flow function (see Figure $6 \mathrm{~b}$, where FF is not necessarily a straight line as shown).
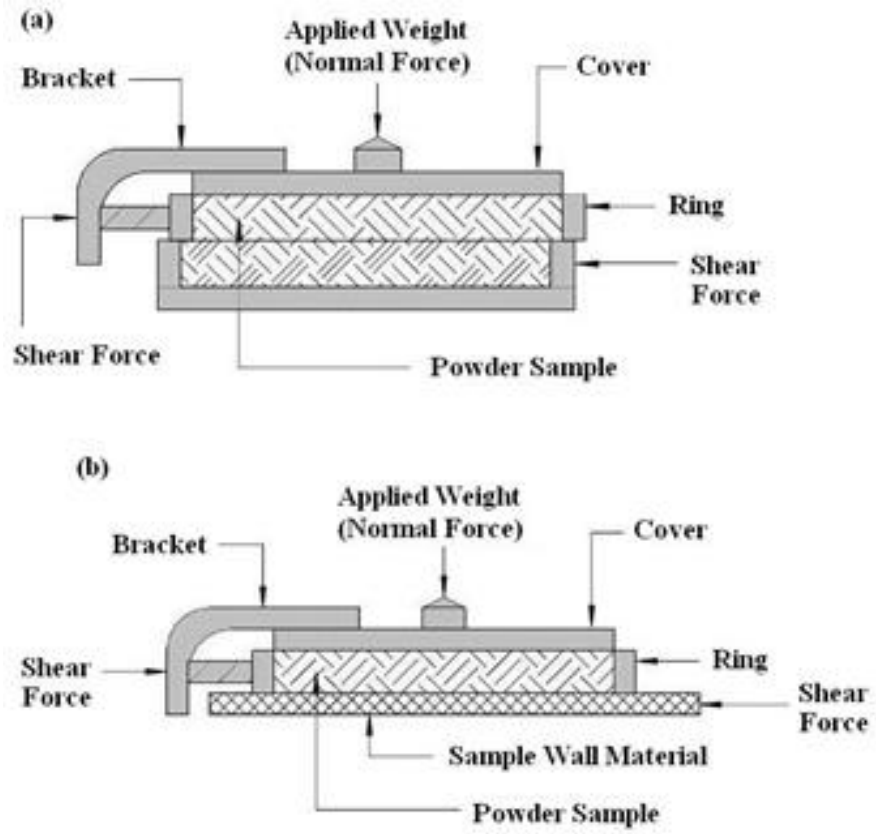

Figure 4: Jenike tester - a) material/material test; b) material/wall test (Chase, 2006). 


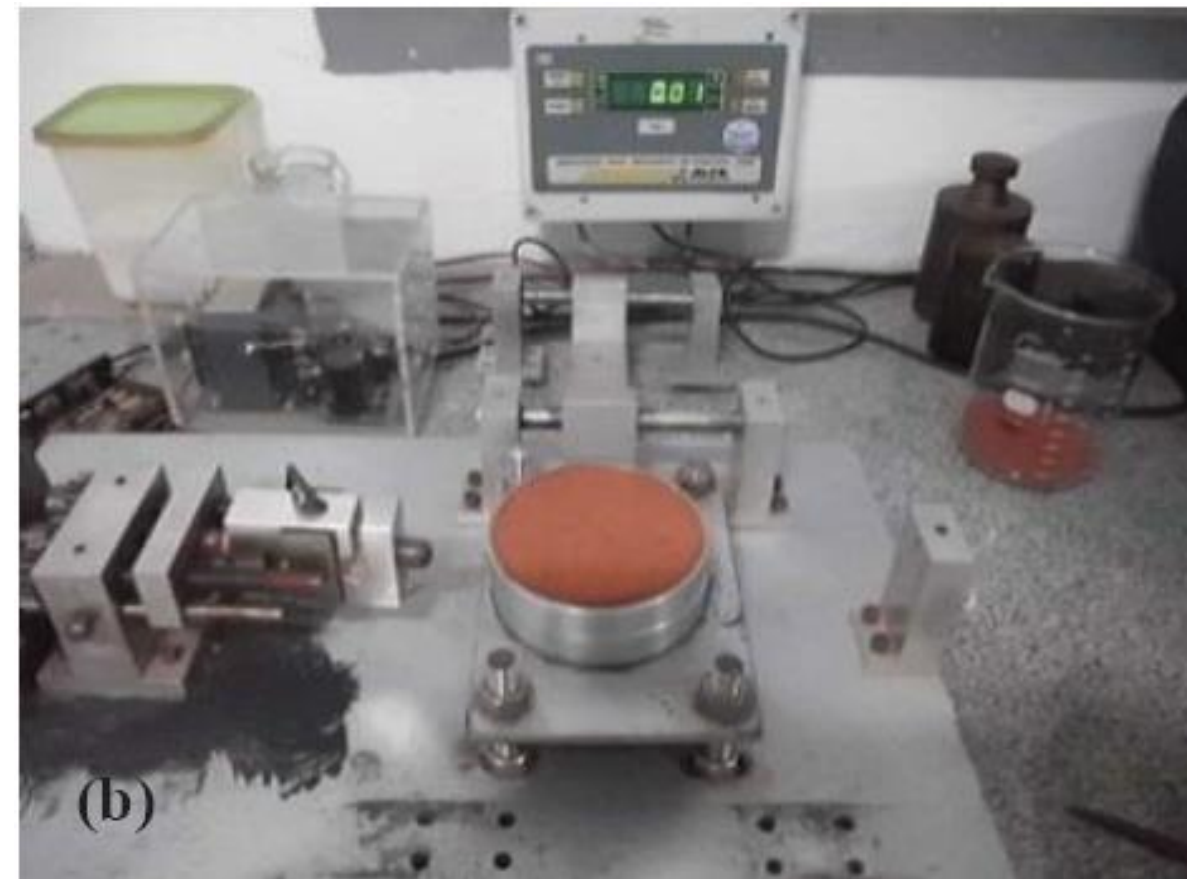

Figure 5: Jenike shear tester used in this work

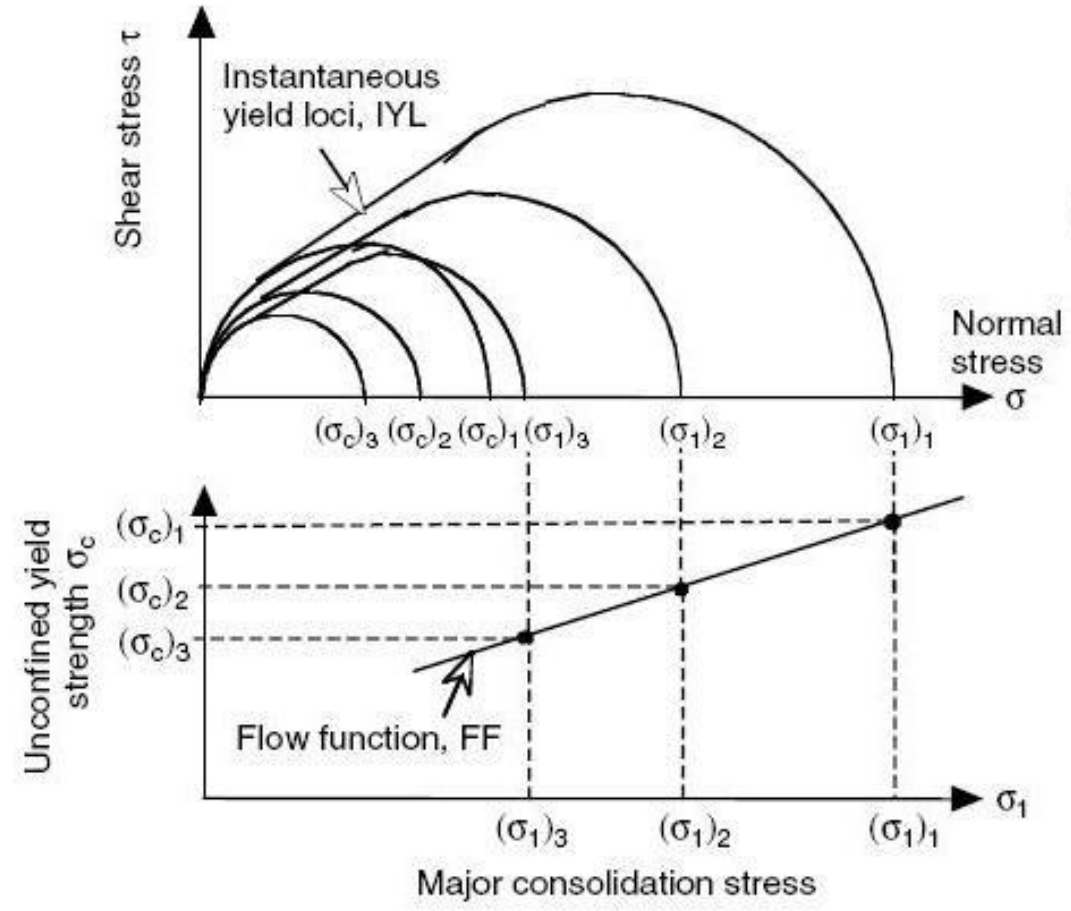

(a)

(b)

Figure 6: a) Mohr semi-circles representing several state stresses; b) The flow function (McGlinchey, 2008).

The flow function FF is the curve $\sigma_{c}\left(\sigma_{1}\right)$ that represents the stress needed to make an arch collapse (in a hopper of silo) as a function of the major compacting stress. Stresses below the FF, the arch is stable. For points above FF, the material is flowing (Chase, 2006). The more the material is cohesive, the larger is $\sigma_{c}$. Non-cohesive materials have small $\sigma_{c}$ values. 


\section{SILO DESIGN FOR FLOW BASED ON JENIKE'S AND ENSTAD'S THEORY}

Jenike's approach (Jenike, 1964) for determination of hopper slope for mass flow is based on the calculation of stresses in hoppers. With the conditions of equilibrium applied to an infinitesimal volume element of bulk solid in the hopper, Jenike derived two partial differential equations. Solution of the system of differential equations exists only for specific combinations of the parameters $\Theta_{c}, \varphi_{e}$, and $\varphi_{x}$, i.e., the conical hopper slope, effective angle of internal friction, and wall friction angle, respectively. The combinations of these parameters determine the flow characteristics in the hopper, as shown in Figure 7. The $\varphi_{\mathrm{e}}$ and $\varphi_{\mathrm{x}}$ are obtained experimentally using a shear tester.

The next step in Jenike's approach is the determination of the minimum diameter of the hopper to avoid arching. If a cohesive arch has formed in a hopper, a force resulting from the weight of the bulk solid is transfered to the hopper walls. This effect is represented by the major stress required to support a stable bulk solid arch, $\sigma_{1}{ }^{\prime}$. The ratio $\mathrm{ff}=\sigma_{1} / \sigma_{1}{ }^{\prime}$ is called flow factor. Jenike provided diagrams for an easy determination of hopper angle (Figure 7 ) and the flow factor (as function of wall friction angle, hopper slope, and effective angle of internal friction), as shown in Figure $8\left(\right.$ for $\varphi_{e}=40^{\circ}$ and $\left.\varphi_{e}=50^{\circ}\right)$.

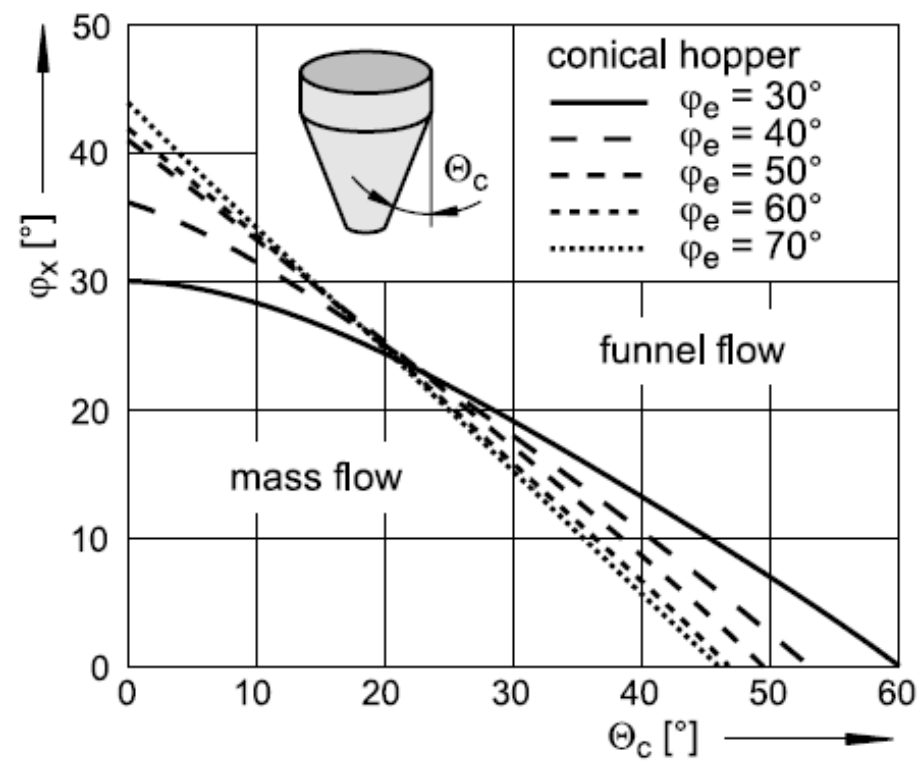

Figure 7: Mass flow diagram for conical hopper (Schulze, 2007).

Once we have defined the flow factor ( $f f$ ) we can obtain the stress $\sigma_{1}{ }^{\prime}$ as a function of stress $\sigma_{1}$ (the slope of the straight line is the arctan of the inverse of $f f$ ). On the same graph, we can insert the flow function curve (FF). At the intersection of the both curves we have the point representing the critical unconfined yield stress $\sigma_{c, \text { crit, }}$ as shown in Figure 9. For values $\sigma_{1}{ }^{\prime}$ above $\sigma_{c}$, the flow occurs, which corresponds to the region to the right from the point of coincidence between the FF and $\operatorname{inv}(f f)$. 

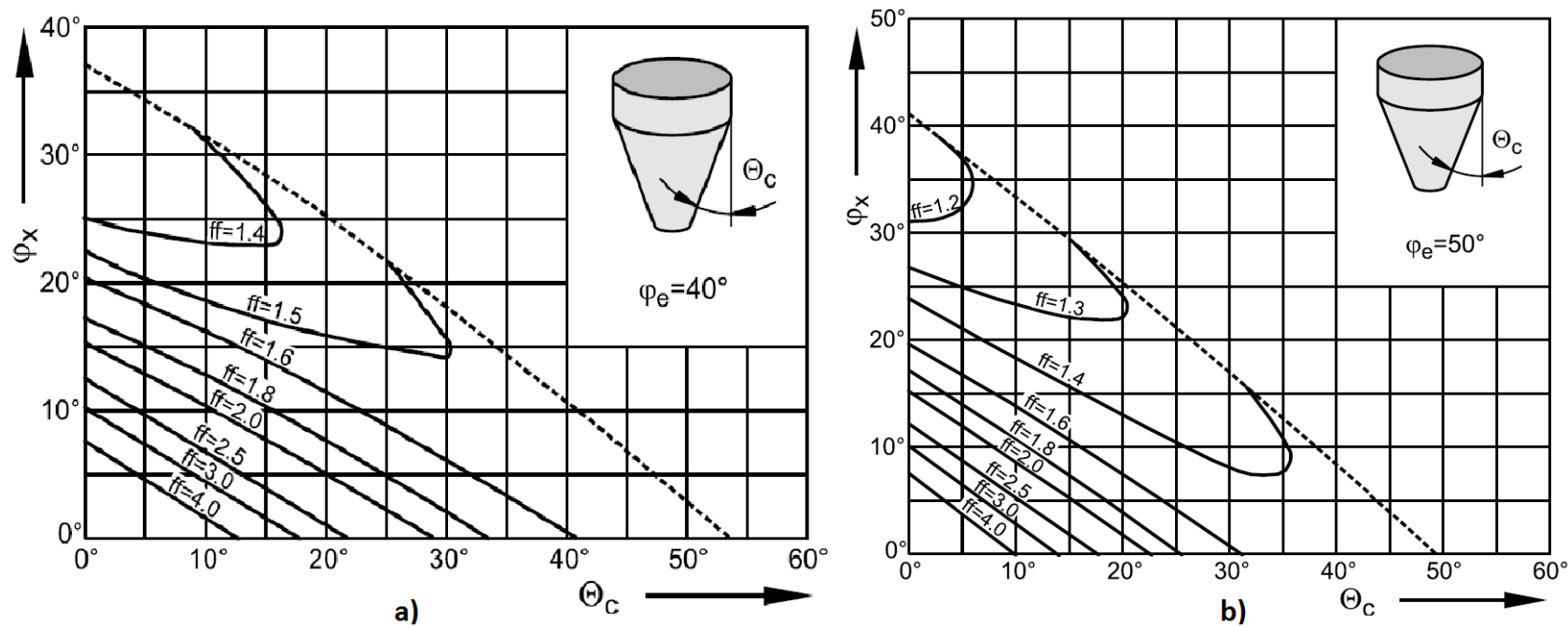

Figure 8: Flow factor, ff, for conical hoppers - a) $\varphi_{e}=40^{\circ}$; b) $\varphi_{e}=50^{\circ}$ (Schulze, 2007).

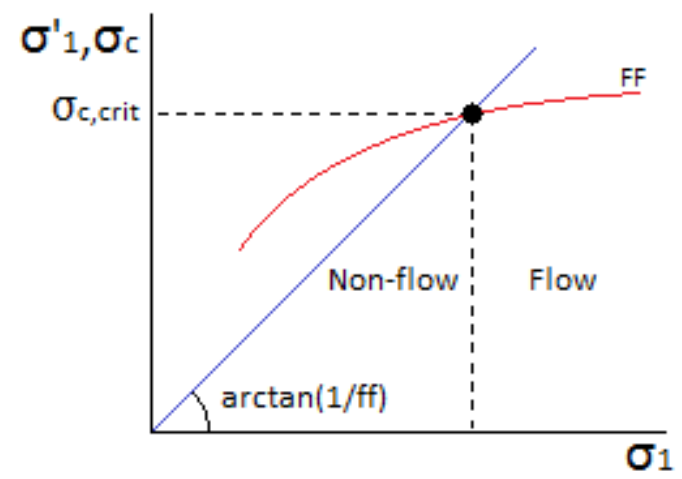

Figure 9: Criterion of flow and non-flow.

Other possibility to calculate the flow factor is by Enstad's theory (1975) with the equations below. First it is defined the function $F\left(\Theta_{c}\right)$, which takes into account the effects of variation of the thickness of the arch with the silo geometry and the hopper angle.

$$
F\left(\Theta_{c}\right)=\left(\frac{65}{130+\Theta_{c}}\right)^{m}\left(\frac{200}{200+\Theta_{c}}\right)^{1-m}
$$

Then, the flow factor is determined by:

$$
\mathrm{ff}=\frac{\mathrm{Y}\left(1+\operatorname{sen} \varphi_{\mathrm{e}}\right)}{2(\mathrm{X}-1) \mathrm{F}\left(\Theta_{c}\right) \cos \left(90-\Theta_{c}\right)}
$$

where:

$$
\begin{aligned}
& 2 \beta=\varphi_{\mathrm{W}}+\operatorname{sen}^{-1}\left(\frac{\operatorname{sen} \varphi_{\mathrm{w}}}{\operatorname{sen} \varphi_{\mathrm{e}}}\right) \\
& \alpha=\beta+\Theta_{c}
\end{aligned}
$$




$$
\begin{aligned}
& X=\frac{2^{m} \operatorname{sen} \varphi_{e}}{1-\operatorname{sen} \varphi_{e}}\left[\frac{\operatorname{sen}(\beta+\alpha)}{\cos \left(90-\Theta_{c}\right)}+1\right] \\
& Y=\left[\frac{\left[2\left(1-\cos \Theta_{c}\right)^{m} \alpha^{1-m_{1}} \cos \left(90-\Theta_{c}\right)+\operatorname{sen} \beta(\operatorname{sen} \alpha)^{1+m}\right]}{\left(1-\operatorname{sen} \varphi_{e}\right)(\operatorname{sen} \alpha)^{2+m}}\right]
\end{aligned}
$$

$\mathrm{m}=1$ for conical hoppers and $\mathrm{m}=0$ for wedge-shaped hoppers; $\varphi_{w}$ is the wall friction angle; $\varphi_{e}$ is the effective angle of internal friction; $\Theta_{c}$ is the hopper angle to vertical.

Once we have calculated $f f$ and determined the critical unconfined yield stress $\sigma_{c, \text { crit, }}$, the minimum diameter (B) of the conical hopper can be found by (Jenike, 1964; Schulze, 2007):

$$
\mathrm{B}=\frac{1000 \mathrm{H}\left(\Theta_{c}\right) \sigma_{c, \text { crit }}}{9,81 \rho}
$$

where:

$$
\mathrm{H}=2+\frac{180 \Theta_{c}}{60 \pi}
$$

\section{RESULTS AND DISCUSSION}

The shear tests were performed according to ASTM (D6128-97) standard. The red mud particle size analysis was performed by sieving method by which can be concluded that the red mud is composed mostly of fine particles, characterized as a cohesive product with average diameter equal to $0.149 \mathrm{~mm}$. It was used the red mud with four different levels of moisture $(1 \%$, $7 \%, 10 \%$, and $13 \%)$. For each moisture level of the material, the Mohr circles were obtained for different levels of pre-consolidation stresses. Figure 10 shows one of these results. The figure shows the Mohr circles obtained for $1 \%$ of moisture and $\sigma_{\text {pre }}=8.3 \mathrm{kPa}$.

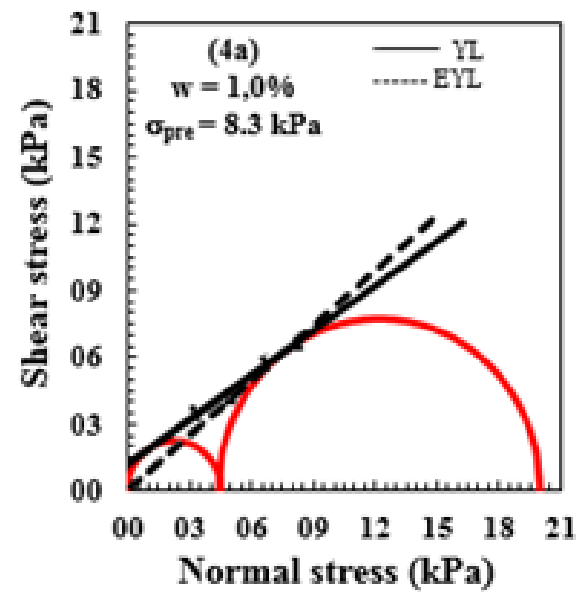

Figure 10: Mohr circles for $1 \%$ of moisture and $\sigma_{\text {pre }}=8.3 \mathrm{kPa}$. 
In order to determine a definitive effective angle of internal friction, for each moisture, it is necessary to join the end-points (E) of the individual yield locus by the best straight line that pass through the origin, and measure its slope (Shamlou, 1990). In Figure 11, we can see the four angles, one for each moisture.

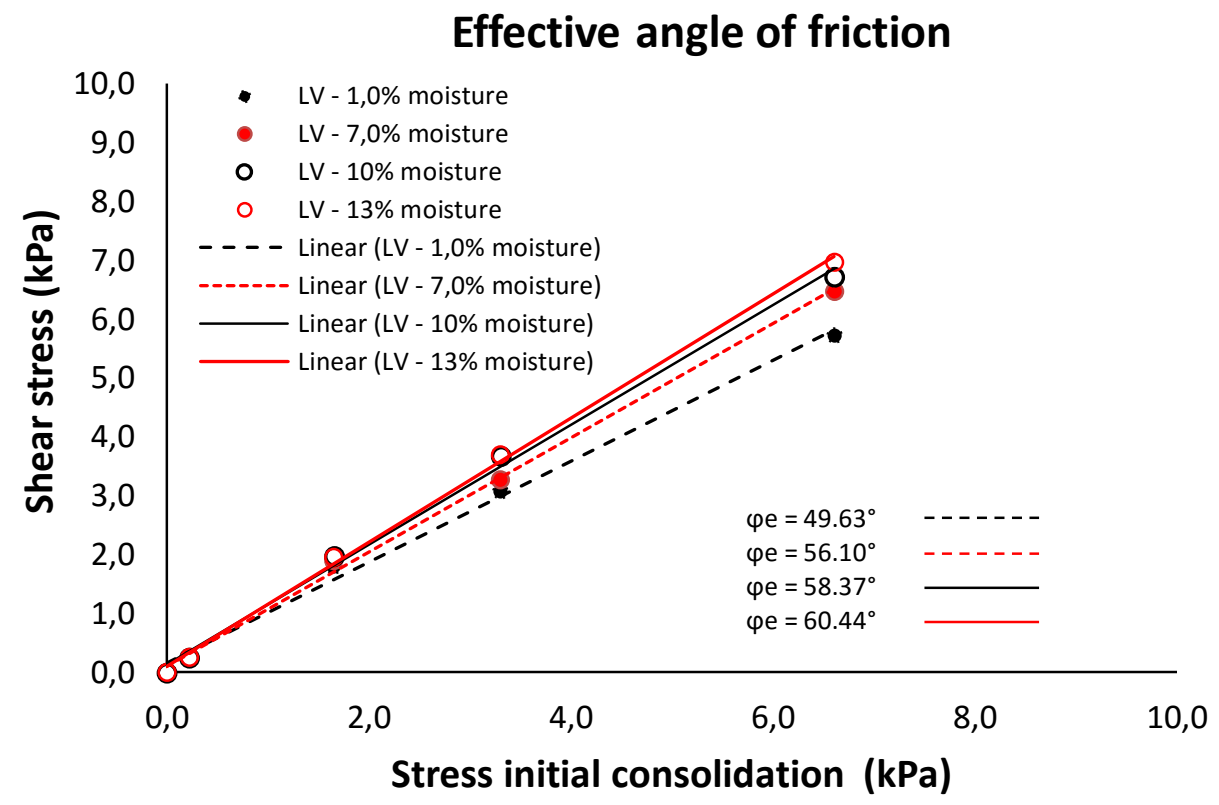

Figure 11: Effective angle of internal friction for different moistures of red mud.

By Jenike cell shear tests it was possible to calculate the density, effective angle of internal friction and wall friction angle for red mud (showed in Table 1). For the determination of the angle of friction between the red mud and silo wall, acrylic surfaces were used in the tests with Jenike shear tester.

Table 1: Effective angle of internal friction, wall friction angle and density as function of moisture of red mud.

\begin{tabular}{c|c|c|c}
\hline Moisture (\%) & $\varphi_{\mathrm{e}}\left(^{\circ}\right)$ & $\varphi_{\mathrm{w}}\left(^{\circ}\right)$ & $\rho \mathrm{kg} / \mathrm{m}^{3}$ \\
\hline 1.0 & 49.63 & 19.86 & 1321 \\
\hline 7.0 & 56.10 & 19.21 & 1342 \\
\hline 10.0 & 58.37 & 18.88 & 1347 \\
\hline 13.0 & 60.44 & 18.72 & 1353 \\
\hline
\end{tabular}

According to Table 1, by Jenike's theory, it was possible to find the hopper slope angle to obtain mass flow. Jenike's theory recommends always decrease three to five degrees of hopper slope angle to avoid turbulences on flow pattern. The flow factor can be found through Jenike's charts or Enstad's theory. Through the crossing of flow function (FF) and flow factor (ff) of the material for different moistures, the critical stresses for each moisture were obtained and the critical diameters were determined (Table 2). Figure 12 shows the diameters values for a silo depending on the moisture, calculated according to Jenike's and Enstad's theories. It can be seen that the Jenike values are more conservatives than Enstad values. 
Table 2: Results of hopper design.

\begin{tabular}{c|c|c|c|c|c|c|c|c}
\hline Moisture (\%) & \multicolumn{2}{|c|}{1} & \multicolumn{2}{c|}{7} & \multicolumn{2}{c|}{10} & \multicolumn{2}{c}{13} \\
\hline$\Theta_{c}\left(^{\circ}\right)$ & \multicolumn{2}{|c|}{23} & \multicolumn{2}{c|}{24} & \multicolumn{2}{c}{23} & \multicolumn{2}{c}{23} \\
\hline Theory & Jenike & Enstad & Jenike & Enstad & Jenike & Enstad & Jenike & Enstad \\
\hline $\mathrm{ff}$ & 1.5 & 1.2749 & 1.4 & 1.2043 & 1.4 & 1.1884 & 1.3 & 1.1734 \\
\hline$\sigma_{c, \text { crit }}(\mathrm{kPa})$ & 1.45222 & 0.941882 & 0.419295 & 0.362659 & 0.752684 & 0.541352 & 0.582342 & 0.524882 \\
\hline $\mathrm{B}(\mathrm{m})$ & 0.2671 & 0.1732 & 0.0764 & 0.0661 & 0.1358 & 0.0976 & 0.1046 & 0.0942 \\
\hline
\end{tabular}

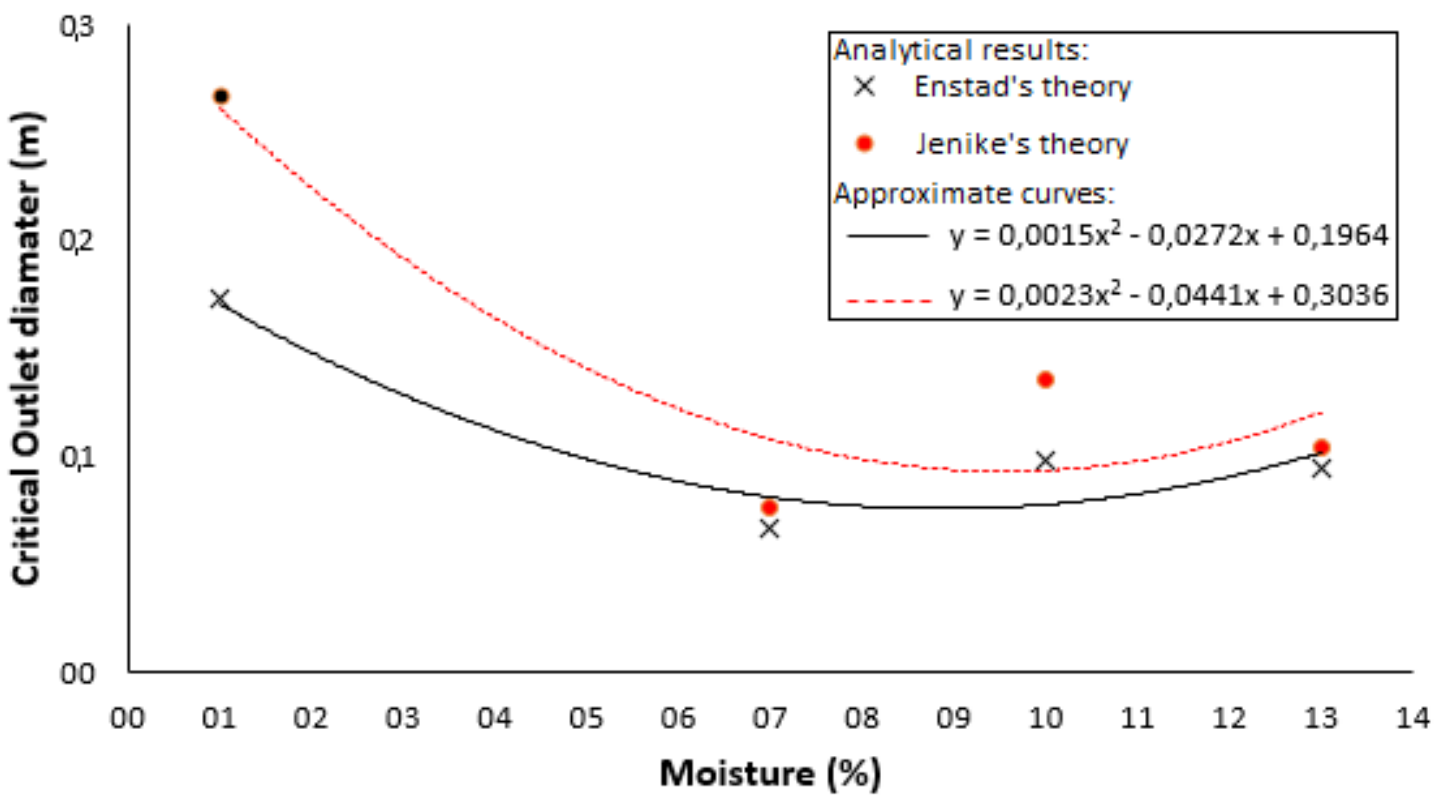

Figure 12: Critical outlet as function of moisture.

Figure 12 shows that in a range of 1 to $13 \%$ of moisture, with $1 \%$ of moisture it is necessary the larger outlet diameter on hopper, and the easier flow is for $7 \%$ of moisture. After $7 \%$, there is an increase in the difficulty of red mud flow.

In order to verify the theoretical results, experiments were performed in the laboratory using a silo made of acrylic (for better visualization of the flow), in this silo it is possible to change the hopper. Therefore, five kinds of hoppers were used in tests, all of them with hopper angle equal or higher than $30^{\circ}$. For each hopper it was tested the flow of the red mud for three different values of moisture $(1 \%, 7 \%$ and $13 \%)$.

The experiments using different acrylic hoppers resulted on funnel flow when arching did not occur. The results confirm the theoretical prediction. Figure 13 shows pictures of those experiments. The pattern of flow at the discharge of the red mud, in all experiments, was found to be the funnel flow type. That fact confirms the theory that the mass flow did not occur when inclination is higher than approximately $23^{\circ}$. 


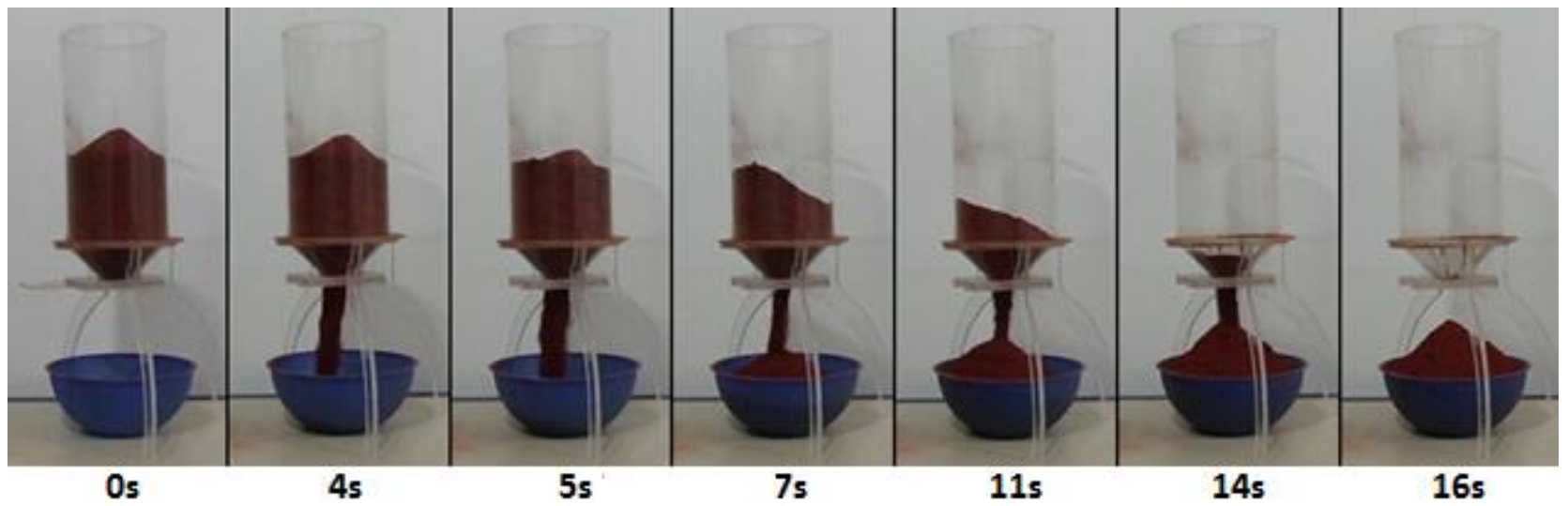

Figure 13: Flow on acrylic silos.

\section{CONCLUSIONS}

This paper shows methodologies to design conical hopper in order to avoid arching in silo discharge. The material used in the study was the red mud (bauxite residue), which proved to be a difficult flowing material, with major facility of flow approximately on $7 \%$ of moisture (within the analyzed range, from $1 \%$ to $13 \%)$. The methodology presented to derive the hopper slope for mass flow was the Jenike diagram. For minimum discharge diameter for avoid arching, it was used two methodologies: Jenike's theory and Enstad's theory. According to the theoretical results, the Jenike theory is more conservative. The results showed that for acrylic silos, in order to have a mass flow of the red mud, the hopper should have a slope $\Theta_{c}$ smaller or equal $23^{\circ}$ and a minimum discharge diameter of $0.2671 \mathrm{~m}$ for range of $1 \%$ to $13 \%$. In order to verify the theoretical results, experiments were performed in laboratory using acrylic silos. As all hoppers have hoppers angle equal or higher than $30^{\circ}$, then the pattern of flow, in all experiments, was found to be funnel flow type, which agrees with the theory.

\section{ACKNOWLEDGEMENTS}

The authors wish to thank FAPESPA (Fundação Amazônia de Amparo a Estudos e Pesquisa do Pará) for financial support.

\section{REFERENCES}

1. ARNOLD, P. C. , MCLEAN, A. G. An analytical solution for the stress function at the wall of a converging channel. v. , Issue 2, p. 255-260, Mar-Apr. 1976a.

2. ARNOLD, P. C. , MCLEAN, A. G. Improved analytical flowfactors for mass-flow hoppers. Powder Technology, v. 15, Issue 2, p. 279-281, Nov-Dec. 1976b.

3. ASTM, 1997. Standard D6128-97, American Society for Testing and Materials.

4. CHASE, G., 2006. "Hopper Design, Solids Processing Course". Available in <http://coel.ecgf.ua kron.edu/ chase>.

5. CHAVES, A. P. Teoria e prática do tratamento de minérios: Manuseio de sólidos granulados, 2011. 
6. ENSTAD, G.G. On the theory of arching in mass flow hoppers. Chemical Engineering Science, v.30, 1975.

7. JENIKE, A. W. Storage and flow of solids. Bulletin No 123, First printing, Engng. Exp. Station, Univ. of Utah, Salt Lake City, USA, 1964.

8. JENIKE, A.W., Storage and flow of solids. Bull. No. 123, 20th Printing, revised 1980. Engng. Exp. Station, Univ. of Utah, Salt Lake City. Available at: The University of Utah, Utah Engineering Experiment Station, 1515 Mineral Square Room 138, Salt Lake City, UT 84112-1109, USA, 1980.

9. KOYNOV, S., GLASSER, B., MUZZIO, F. Comparison of three rotational shear cell testers: Powder flowability and bulk density. Powder Technology, v. 283, p. 103-112, 2015.

10. LIU, Z., LI, H. Metallurgical process for valuable elements recovery from red mud - A review. Hydrometallurgy, n. 155, p. 29-43, 2015.

11. LOPES NETO, J. P., NASCIMENTO, J. W. B. Características de fluxo e projeto de tremonhas cônicas em silos verticais. Revista Brasileira de Engenharia Agrícola e Ambiental, v. 17, n. 3, p. 339-345, 2013.

12. MARINELLI, J., CARSON, J. W. Solve solids flow problems in bins, hoppers, and feeders, Chemical Engineering Progress, p. 22-28, May, 1992.

13. MCGLINCHEY, D. Bulk solids handling - Equipment selection and operation. Blackwell Publishing, 2008.

14. MERCURY, J. M. R.; GALDINO, L. G.; VASCONCELOS, N. S. L. S.; PAIVA, A. E. M.; CABRAL, A. A.; ANGÉLICA, R.S. Estudo do comportamento térmico e propriedades físico-mecânicas da lama vermelha. Matéria (Rio), v. 15, n. 3, p. 445-460, 2010.

15. SCHULZE, D. Powder and bulk solids. Springer, 2007.

16. SHAMLOU, P. A. Handling of Bulk Solids: Theory and Practice, 1990.

17. SILVA FILHO, E. B., ALVES, M. C. M., MOTTA, M. Lama vermelha da indústria de beneficiamento de alumina: produção, características, disposição e aplicações alternativas. Matéria (Rio), v. 12, n. 2, p. 322-338, 2007.

18. SILVA FILHO, E. B., ALVES, M. C. M., MOTTA, M., OLIVEIRA, E. H. C., BRANDER JUNIOR, W. Estudo sobre a utilização da lama vermelha para a remoção de corantes em efluentes têxteis. Quim. Nova, v. 31, n. 5, p. 985-989, 2008.

19. SOUZA, J. A. S. Estudo e Avaliação do uso de Resíduos do Processo Bayer como Matéria Prima na Produção de Agregados Sintéticos Para a Construção Civil. Belém-PA. Ph.D. thesis - Federal University of Pará (UFPA), 2010.

20. SUN, C. C. Quantifying effects of moisture content on flow properties of microcrystalline cellulose using a ring shear tester. Powder Technology, v. 289, p. 104-108, 2016.

21. WALKER, D. M. An approximate theory for pressures and arching in hoppers. Chemical Engineering Sciences, v. 21, p. 975-997, 1966. 